\title{
THE PROMOTION OF SALT QUALITY THROUGH OPTIMIZING BRINE CONCENTRATION A NEW TECHNIQUE "BIDIRECTIONAL BRINE CONCENTRATION"
}

\section{J. ZHILING* \\ Y. GUANGYU}

Salt Research Institute,

China National Salt Industry Corporation

831 Yingkou Road, Tanggu, Tianjin, 300450, P.R. China

Received: $15 / 12 / 08$

Accepted: 30/12/08

*to whom all correspondence should be addressed: e-mail: jinzhiling66@sina.com

\begin{abstract}
The commonly accepted brine concentration practice in most Chinese Northern solar works is to pump the sea water into salt works and then let it go through a physical changing process of natural evaporation, condensation and crystallization, during which, weather factor and the soil nature have to be taken into consideration when determining the technologic parameters such as brine depth, brine protection area, fresh water drainage rate and so on. Meanwhile, different methods should be employed according to various weather conditions, for example, brine is concentrated with decided depth and salinity over periods of stable weather conditions (Spring); rapid brine concentration by deep storage and lower depth brine should be used during rainy seasons; and in winters, the amount should be increased to keep the salinity.
\end{abstract}

However, accompanying this physical changing process of salt production is balancing process of the amount of multi-biology in brine. Every salt work fosters an ecosystem, which includes algae, bacteria, protoza, menatoza, artemia, sea weed and fish communities.

The low salinity brine is featured of a myriad of algae, which are able to synthesize and accumulate pigments, elevate the brine's absorbency of solar energy and quicken the evaporation speed; the algae, bacteria, organic and inorganic substances on the salt ponds floor may form a biological pad, performing the functions of brine purifying, soil improvement and leakage protection. At the same time, the biological pad can block out large amount of elements and trace elements in the mud on the salt pond floor and the bacteria can effectively decompose organic crumbs of the solar salt works ecosystem.

The medium salinity brine is dominated by artemia, who are good at sieving the algae, organic and inorganic substances in brine so as to purify it. The artemia corpse are sources of protein for red halobacteria, which are capable of increasing the brine staining ability, purifying brine and promoting the evaporation amount and the salt quality.

In conclusion, a balanced ecosystem is beneficial to salt industry by :

A. culturing bentic communities, available for seizing nutrition and controlling leakage;

B. staining brine to enhance the absorbency of solar energy and evaporation rate;

C. being able to decompose most of its self-generated organics.

The Bidirectional Brine Concentration Technology is meant supplementing the ordinary brine concentration with ecosystem management, namely, through the artificial adjustment of the amount of biology to reach the eco-balance. This is composed of two parts:

A. The bio-management of artemia. Combining the concentrated multiplication with culturing during the whole production process to adjust the community density to a suitable level and keep the eco-balance in line with scientific standards. As long as the brine salinity reaches certain level and the artemia food chain starts loosing balance, we will fish over-thick community and let the resting artemia die in the high salinity area and their corpse will be used for the source of protein for halobecteria. 
B. Selecting and culturing excellent breed of halobacteria.. Let red halobacteria reproduce in saturated brine and crystallizers and contact a corresponding scientific surveillance. This helps heighten the brine transparency, lower the brine stickiness and promote the salt quality.

KEYWORDS: solar salt, saltponds ecosystem, brine concentration , crystallization.

\section{INTRODUCTION}

The annual production and quality of solar salt are influenced significantly with climatic condition. After four year studying in a solar salt works, the author and her colleagues proposed Bidirectional Brine Concentrating Technique to improve salt quality and yield. The technique combines physical process and biological manipulation in the process of salt production, which is considered as the effective way in Northern China.

\section{BIDIRECTIONAL BRINE CONCENTRATING TECHNIQUE}

The commonly accepted brine concentrating technique in solar works in Northern China is to pump seawater into primary evaporation pond and then produce salt through series of physical process under nature conditions such as evaporation, condensation and crystallization. Climate and soil parameters need to be taken into consideration when determining the technique parameters such as brine water depth, brine protection area and fresh water drainage rate. It needs to stress that this physical process is balanced with biological community existed in brine water ecosystem, which is consist of algae, bacteria, protoza, nematode, Artemia, seaweed and fish.

The low salinity brine is dominated by many algae species, which synthesize and accumulate pigments, increase solar energy absorption and speed up evaporation in salt pond. The combination of algae, bacteria, organic and inorganic substances form biological mats on the bottom of salt ponds, which remove dissolved nutrient mineral from the water, prevent water leakage and improve soil condition. It can also block large amount of elements and trace elements in the mud, facilitate organic detritus decomposition. The medium salinity brine is dominated by Artemia, which filter algae, organic and inorganic substances existed in brine, therefore purify brine water. The dead Artemia are the protein source for halobacteria, which increase the brine color, purify brine and speed up evaporation, result in the formation of larger salt crystals. According to above theory, the bidirectional brine concentrating technique was applied to promote brine concentrating capacity and raw salt quality (See figure 1).

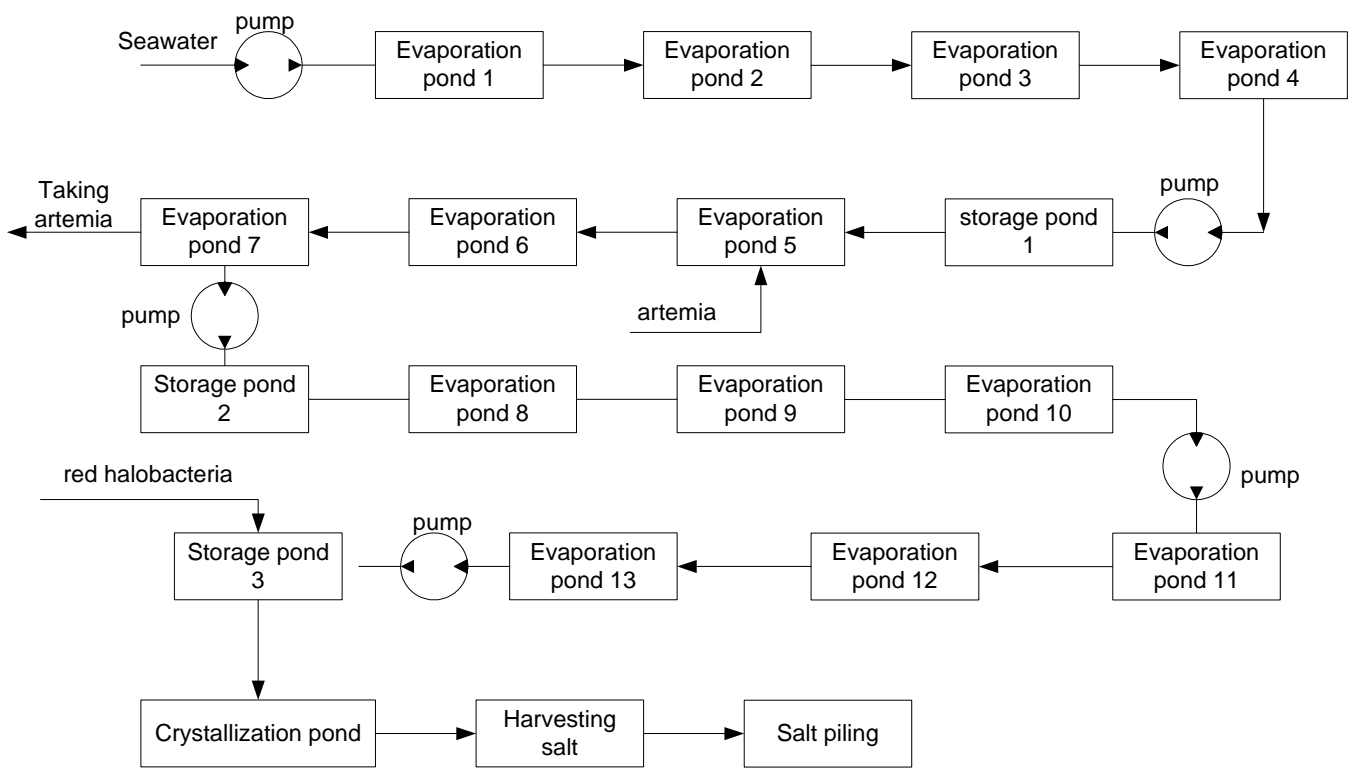

Figure 1. Bidirectional brine concentration process 


\subsection{INORGANIC SALT PRODUCTION TECHNIQUE}

Different measurements should be applied according to various climatic conditions. In spring (less rainfall and high evaporation rate), brine is concentrated through fixed ratio of sodium and magnesium, fixed water flow rate, fixed water depth and concentration; while in summer (high rainfall and evaporation), rapid brine concentrating should be done via shallow water depth. In autumn and winter (low temperature and less evaporation), the brine concentration should be stabilized, meanwhile increase brine storage as much as possible.

It is important to utilize evaporation rate rationally and improve evaporation effectiveness during seasonal transition. In the transition from winter to spring (in the period of later February to earlier March), along with temperature raising, brine concentrating should be done by the means of enlarging saturated brine area, turning medium salinity brine into high salinity brine and further into saturated brine, storing enough amount of saturated brine for salt harvesting. In the transition from spring to summer (mid of May to earlier July), brine concentrating should be accelerated by decreasing water depth, turning low salinity brine into medium salinity brine and further into high salinity and saturated brine. In order to prevent brine diluting from rainfall, fast concentrating and deep brine storage should be applied in this period.

\subsection{BIOLOGICAL MANAGEMENT OF SALT WORKS}

The Biological management needs to be applied in the process of brine concentrating by means of biomass manipulation in brine.

A. The bio-management of Artemia. The density of Artemia should be manipulated by combining intensive culture and extensive culture during whole production process and in line with scientific standards. As soon as the brine salinity reaches certain level and the Artemia food chain starts loosing balance. Artemia biomass need to be harvested, remaining Artemia die in the crystallization pond which is decomposed and used as protein source for halobecteria.

B. Halobacteria selection and propagation. Halobacteria should be selected and propagated from saturated brine and crystallization ponds, as well as manipulated carefully. It helps enhance the brine transparency, lower the brine viscosity and improve salt quality.

\section{RESULTS}

To testing the effect of this process, one unite of a solar saltworks in the northern of China was selected for our pilot plant, whose total area is 268.72 he., and its effective area for evaporation is 222.26 he., for crystallization is 12.57 he., and the using area coefficient is 87.4 $\%$, average capacity is about 20,000 tons one year. Due to the rule of brine concentration and its distribution condition, the pilot plant is divide into five parts, such as the low salinity ponds, the medium salinity ponds, the high salinity ponds, the buffer ponds and the crystallization ponds. The above ponds detail data are presented in figure 2 . The brine drainage of pilot plant goes by two different ways: one way of the brine is letting through a bidirectional brine concentration process, and the other way goes as the contrast of the former process though within the same route.

Table 1. Biological and Chemical Parameters of Middle Salinity Brine

\begin{tabular}{llll}
\hline Item & $\begin{array}{l}\text { Surface } \\
\text { (ha) }\end{array}$ & Proportion & $\begin{array}{l}\text { Brine concentration } \\
\left({ }^{\circ} \mathrm{Be}^{\prime}\right)\end{array}$ \\
\hline Low salinity pond & 112.43 & $47.9 \%$ & $3.0-5.5$ \\
\hline Medium salinity pond & 58.64 & $25.0 \%$ & $6.0-10.0$ \\
\hline High salinity pond & 28.74 & $12.2 \%$ & $11.0-17.0$ \\
\hline Buffer pond & 22.43 & $9.6 \%$ & $19.0-26.0$ \\
\hline Crystallization pond & 12.57 & $5.4 \%$ & $19.0-26.0$ \\
\hline Total & 234.83 & $100 \%$ & \\
\hline
\end{tabular}


In the low salty ponds, the concentration and depth of brine is controlled. In the middle salty ponds, the larva of the artemia are inoculated, during this period, the brine concentration, the brine temperature and its fluidity all should be kept in stabilization, then half a month later, the first generation artemia is grown up and strong enough to gain the predominance in brine biology, so the algae are eaten up soon. In the high salty ponds and the crystallization ponds, a red temperature-resistant and salt-resistant halophilic bacteria is incubated and inoculated, whose number can reach $10^{6} \mathrm{ml}^{-1}$, and then monitor the transmittance and viscosity of the brine (Shown in Figures 3, 4 and 5).

Table 2. Collection Data Of Medium-Salinity Brine

\begin{tabular}{|c|c|c|c|c|}
\hline No & Item & $\begin{array}{l}\text { Experimental } \\
\text { pond }\end{array}$ & $\begin{array}{l}\text { Control } \\
\text { ponds }\end{array}$ & Effect \\
\hline 1 & Biomass $\left(\mathrm{g} \mathrm{m}^{-3}\right)$ & 1.05 & 0.57 & $+84.2 \%$ \\
\hline 2 & Algal $\left(\times 10^{6} \mathrm{ml}^{-1}\right)$ & 7.80 & 15.50 & $-49.7 \%$ \\
\hline 3 & Transmittance $(\mathrm{T})$ & 97.80 & 95.50 & $+2.4 \%$ \\
\hline 4 & Organic carbon $\left(\mathrm{mg} \mathrm{l}^{-1}\right)$ & 15.50 & 21.60 & $-28.2 \%$ \\
\hline 5 & Viscosity (mpa s) & 2.24 & 2.35 & $-4.7 \%$ \\
\hline 6 & $\mathrm{Ca}^{2+}\left(\mathrm{g} \mathrm{I}^{-1}\right)$ & 0.86 & 1.00 & $-14.0 \%$ \\
\hline 7 & Suspend matter $\left(\mathrm{g} \mathrm{l}^{-1}\right)$ & 0.112 & 0.125 & $-10.4 \%$ \\
\hline 8 & Soluble $\mathrm{N}\left(\mathrm{mg} \mathrm{l}^{-1}\right)$ & 7.00 & 6.60 & $+6.1 \%$ \\
\hline 9 & diaphaneity $(\mathrm{cm})$ & 76.00 & 59.80 & $+27.1 \%$ \\
\hline
\end{tabular}

Note: all the value is average statistic value.

Table 3. Brine Concentration Of High-Salinity Ponds ${ }^{\circ} \mathrm{Be}$ '

\begin{tabular}{lllccc}
\hline No. & Time & Sampling spot & Pond No. 8 & Pond No.9 & Pond No.10 \\
\hline \multirow{2}{*}{04} & $04-06-1995$ & Experimental pond & 12.6 & 14.4 & 15.0 \\
\cline { 3 - 6 } & & Control pond & 10.3 & 11.4 & 12.7 \\
\hline 2 & $04-08-1995$ & Experimental pond & 12.7 & 14.5 & 15.0 \\
\cline { 3 - 6 } & & Control pond & 11.0 & 12.3 & 13.2 \\
\hline \multirow{2}{*}{05} & $05-25-1995$ & Experimental pond & 12.2 & 14.1 & 15.4 \\
\cline { 3 - 6 } & & Control pond & 10.7 & 12.4 & 14.0 \\
\hline \multirow{2}{*}{06} & $06-07-1995$ & Experimental pond & 12.8 & 14.5 & 15.5 \\
\cline { 3 - 6 } & & Control pond & 11.4 & 12.7 & 14.2 \\
\hline 5 & $06-12-1995$ & Experimental pond & 12.6 & 14.1 & 16.0 \\
\cline { 3 - 6 } & & Control pond & 11.8 & 12.7 & 14.8 \\
\hline 6 & $09-05-1995$ & Experimental pond & 10.8 & 12.3 & 13.1 \\
\cline { 3 - 6 } & & Control pond & 8.9 & 10.1 & 11.2 \\
\hline 7 & $10-11-1995$ & Experimental pond & 9.2 & 11.2 & 12.6 \\
\cline { 3 - 6 } & & Control pond & 8.4 & 9.6 & 10.8 \\
\hline
\end{tabular}

Seen from figure 3 and figure 4, the amount of biomass in brine increased evidently after the artemia are inoculated in the middle salty ponds, with the algae decreased, the transmittance and the transparence added, the suspend substance reduced, which shows that artemia can clean the brine, strengthen the evaporation of brine, enhance the capability of preparing brine. Chart 4 shows, when halophilic bacteria are inoculated, the viscosity of saturated brine is fallen, its transmittance added, and the concentration of $\mathrm{Ca}^{2+}$ lowered, which indicates that, the red halophilic bacteria can add the brine to absorb more solar energy, accelerate the evaporation velocity and increase the salt production.

By using bidirectional brine concentration technology, the quality of the raw salt has increased $0.8 \% \sim 1.7 \%$ (figure 6), and the amount of $\mathrm{Ca}^{2+}, \mathrm{Mg}^{2+}$ are also lowered evidently. 
Table 4. Parameters of Saturated Brine in Crystallization Pond

\begin{tabular}{|c|c|c|c|c|c|}
\hline No. & time & Sampling spot & $\begin{array}{c}\text { Transmittance } \\
(\mathrm{T})\end{array}$ & $\begin{array}{c}\text { Viscosity } \\
\text { (mpa s) }\end{array}$ & $\begin{array}{l}\mathrm{Ca}^{2+} \\
\left(\mathrm{g} \mathrm{l}^{-1}\right)\end{array}$ \\
\hline \multirow[t]{2}{*}{1} & \multirow[t]{2}{*}{ 08-25-1993 } & Experimental pond & 87.2 & 3.50 & 0.0332 \\
\hline & & Control pond & 86.3 & 3.85 & 0.0387 \\
\hline \multirow[t]{2}{*}{2} & \multirow[t]{2}{*}{ 09-09-1993 } & Experimental pond & 83.8 & 3.70 & 0.051 \\
\hline & & Control pond & 86.7 & 3.80 & 0.077 \\
\hline \multirow[t]{2}{*}{3} & \multirow[t]{2}{*}{$11-24-1993$} & Experimental pond & 90.4 & 5.4 & 0.07 \\
\hline & & Control pond & 91.5 & 5.65 & 0.09 \\
\hline \multirow[t]{2}{*}{4} & \multirow[t]{2}{*}{ 04-25-1994 } & Experimental pond & 67.5 & 3.15 & 0.076 \\
\hline & & Control pond & 77.5 & 3.36 & 0.093 \\
\hline \multirow[t]{2}{*}{5} & \multirow[t]{2}{*}{ 05-16-1994 } & Experimental pond & 83.8 & 4.80 & 0.051 \\
\hline & & Control pond & 84.5 & 3.28 & 0.076 \\
\hline \multirow[t]{2}{*}{6} & \multirow[t]{2}{*}{ 05-30-1994 } & Experimental pond & 78.5 & 3.95 & 0.06 \\
\hline & & Control pond & 73.2 & 4.13 & 0.04 \\
\hline \multirow[t]{2}{*}{7} & \multirow[t]{2}{*}{ 06-28-1994 } & Experimental pond & 77.2 & 2.37 & 0.05 \\
\hline & & Control pond & 64.8 & 4.65 & 0.04 \\
\hline \multirow[t]{2}{*}{8} & \multirow[t]{2}{*}{ 07-11-1994 } & Experimental pond & 77.2 & 3.49 & 0.06 \\
\hline & & Control pond & 67.9 & 4.61 & 0.05 \\
\hline \multirow[t]{2}{*}{9} & \multirow[t]{2}{*}{ 07-26-1994 } & Experimental pond & 78.7 & 3.85 & 0.04 \\
\hline & & Control pond & 68.4 & 5.30 & 0.06 \\
\hline \multirow[t]{2}{*}{10} & \multirow[t]{2}{*}{ 08-11-1994 } & Experimental pond & 84.3 & 3.52 & 0.04 \\
\hline & & Control pond & 80.1 & 3.71 & 0.06 \\
\hline \multirow[t]{2}{*}{11} & \multirow[t]{2}{*}{ 08-26-1994 } & Experimental pond & 78.8 & 5.20 & 0.03 \\
\hline & & Control pond & 63.7 & 7.80 & 0.03 \\
\hline \multirow[t]{2}{*}{12} & \multirow[t]{2}{*}{ 08-24-1994 } & Experimental pond & 92.9 & 3.80 & 1.32 \\
\hline & & Control pond & 82.5 & 3.70 & 1.43 \\
\hline \multirow[t]{2}{*}{13} & \multirow[t]{2}{*}{ 09-12-1995 } & Experimental pond & 90.6 & 4.60 & 0.94 \\
\hline & & Control pond & 84.4 & 4.25 & 1.96 \\
\hline \multirow[t]{2}{*}{14} & \multirow[t]{2}{*}{ 09-25-1995 } & Experimental pond & 93.2 & 3.60 & 2.34 \\
\hline & & Control pond & 90.6 & 3.45 & 1.94 \\
\hline
\end{tabular}

Table 5. Chemical Composition of Raw Salt from Crystallization Pond

\begin{tabular}{|c|c|c|c|c|c|c|c|}
\hline \multirow{2}{*}{ No } & \multirow{2}{*}{ Sampling spot } & \multicolumn{6}{|c|}{ Chemical composition ( $\%$ ) } \\
\hline & & $\mathrm{NaCl}$ & $\mathrm{MgCl}_{2}$ & $\mathrm{MgSO}_{4}$ & $\mathrm{CaSO}_{4}$ & moisture & insoluble \\
\hline \multirow[t]{2}{*}{1} & $\begin{array}{l}\text { Experimental } \\
\text { crystallization pond } \\
1\end{array}$ & 97.06 & 0.24 & 0.04 & 0.65 & 1.52 & 0.10 \\
\hline & $\begin{array}{l}\text { Control } \\
\text { crystallization pond } \\
1\end{array}$ & 95.37 & 0.43 & 0.20 & 0.61 & 3.66 & 0.13 \\
\hline \multirow[t]{2}{*}{2} & $\begin{array}{l}\text { Experimental } \\
\text { crystallization pond } \\
2\end{array}$ & 94.60 & 0.75 & 0.04 & 0.44 & 3.66 & 0.09 \\
\hline & $\begin{array}{l}\text { Control } \\
\text { crystallization pond } \\
2\end{array}$ & 93.88 & 0.85 & 0.26 & 0.61 & 3.67 & 0.16 \\
\hline
\end{tabular}




\section{CONCLUSIONS}

By means of biological management, the application of bidirectional brine concentrating technique results in the improvement of salt quality and production. The balance of ecosystem is achieved through biomass manipulation in brine water: preventing leakage by the algae mat in low salinity pond; purifying brine by Artemia in medium salinity pond; increasing water coloration, decreasing brine viscosity and improving water evaporation by the function of halobacteria in crystallization pond.

Now, in the north of China, a few large salt plants, which production capacity is above $1,000,000$ tons one year, for example, Tanggu Salt Plant, Hanggu Salt Plant, Nanpu Salt Plant, choose the Bidirectional Brine Concentration Technique to decrease the rate of evaporation area to crystallization, increase the brine concentration capacity and raw salt quality.

The Bidirectional Brine Concentration Technique is meant supplementing the ordinary brine concentration with ecosystem management, namely, through the artificial adjustment of the amount of biomass to reach the ecosystem balance. This is composed of two parts:

A. The bio-management of artemia. Combining the concentrated multiplication with culturing during the whole production process to adjust the community density to a suitable level and keep the eco-balance in line with scientific standards. As long as the brine salinity reaches certain level and the artemia food chain starts loosing balance, we will fish over-thick community and let the resting artemia die in the high salinity area and their corpse will be used for the source of protein for halobecteria.

B. Selecting and culturing excellent breed of halobacteria.. Let red halobacteria bacteria reproduce in saturated brine and crystallizers and contact a corresponding scientific surveillance. This helps heighten the brine transparency, lower the brine stickiness and promote the salt quality.

\section{REFERENCES}

1. Zhu Lixiang, Sun Juju, (1995) Function of saltponds ecosystem and its management method, Sea-lake salt and chemical industry, 24(1).

2. Chen Gang, Zhang Guizhen, (1997) Control method for nutrient-rich saltponds ecosystem, Sea-lake salt and chemical industry, 26(2). 